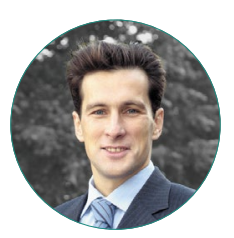

А. С. Адельфинский

\title{
ПРИЧИНЫ БЕГОВОГО БУМА 2010-Х: КЕЙС-СТАДИ КРУПНЕЙШЕГО МАРАФОНА РОССИИ
}

\section{Правильная ссылка на статью:}

Адельфинский А. С. Причины бегового бума 2010-х: кейс-стади крупнейшего марафона России // Мониторинг общественного мнения: экономические и социальные перемены. 2021. № 4. C. 275-299. https://doi.org/10.14515/monitoring.2021.4.1925.

\section{For citation:}

Adelfinsky A.S. (2021) Causes of the 2010 Running Boom: Case Study of the Russia's Largest Marathon. Monitoring of Public Opinion: Economic and Social Changes. No. 4. P. 275-299. https://doi.org/10.14515/monitoring.2021.4.1925. (In Russ.) 
ПРИЧИНЫ БЕГОВОГО БУМА 2010-Х: КЕЙС-СТАДИ КРУПНЕЙШЕГО МАРАФОНА РОССИИ

АДЕЛЬФИНСКИЙ Андрей Станиславович - кандидат экономических наук, доцент кафедры "Экономика и бизнес", МГтУ им. Н. Э. Баумана, Москва, Россия E-MAIL: adelfi@mail.ru

https://orcid.org/0000-0003-0690-8848

Аннотация. В статье изучен кейс трансформации крупнейшего марафона России (в 1981-2012 гг. Московский международный марафон мира, с 2013 г.- Московский марафон). С 2011 по 2016 г. число его участников выросло в восемь раз. Масштабность изменений заставляет говорить о фитнес-буме 2010-х годов. Пресса присуждает лавры успеха возникшему малому бизнесу по организации массовых событий-но заслуженно ли?

Методы исследования: анализ беговой статистики и документов - календарей, результатов и положений массовых забегов; анализ публикаций в прессе и интернете; включенное наблюдение в практике бега.

Результаты кейс-стади выявили четыре ведущих фактора бегового бума. Во-первых, это наследие фитнес-бума 1970-1980-х годов, позволяющее говорить о 2010-х как о второй волне. Во-вторых, кампании по популяризации массового бега транснациональных брендов Nike и Adidas, создавшие "точку входа" в практику массового бега. Подробно описана кампания Nike We Run Moscow 2010-2015. B-третьих, трансформация медиасреды, облегчившая распространение
CAUSES OF THE 2010 RUNNING BOOM: CASE STUDY OF THE RUSSIA'S LARGEST MARATHON

Andrey S. ADELFINSKY ${ }^{1}-$ Cand. Sci. (Econ.), Associate Professor at the Department of Economics and Bussines E-MAIL: adelfi@mail.ru https://orcid.org/0000-0003-0690-8848

\footnotetext{
${ }^{1}$ Bauman Moscow State Technical University, Moscow, Russia
}

Abstract. The article examines the case of the transformation of the largest marathon in Russia (in 1981-2012: Moscow International Peace Marathon, since 2013 - Moscow Marathon). From 2011 to 2016, the number of its participants increased eightfold. The extent of the changes made us talk about the fitness boom of the 2010s. The press awards the laurels of success to the emerging small business in the field of organization of mass events - but is it true? In our research we used the following methods: analysis of running statistics and documents - calendars, results and regulations of mass races; analysis of publications in the press and on the Internet; overt observation in the running. The case study revealed four leading drivers of the running boom. Firstly, it is the legacy of the 1970s and 1980s fitness boom, allowing to speak of the 2010s as the second wave. Secondly, the campaigns for popularization of mass running undertaken by the multinational brands Nike and Adidas have created an "entry point" into the mass running practice. Nike We Run Moscow campaign 2010-2015 is described in detail. Thirdly, the transformation of media made it easier for these campaigns to spread. Fourthly, the change in the local political situation that influenced the 
этих кампаний. В-четвертых, изменение локальной политической конъюнктуры, повлиявшее на траекторию бума. Следствием первоначального роста и еще одним дополнительным фактором фитнес-бума действительно стали "предприниматели от бега", но их появление связано с перераспределением административных ресурсов, а не с открытием "новой ниши". Возникли побочные эффекты предпринимательства: джентрификация бега, коммерциализация с 18-кратным ростом взносов, снижение доступности участия.

Обсуждение развивает дискуссию о моделях спорта. Мы полагаем, что пропагандировать "физкультуру ради здоровья" беспредметно, а причина низкого уровня вовлеченности - сложившаяся проолимпийская модель, дисфункциональная для неэлитного спорта. Необходимо внедрение экспрессивной модели и репозиционирование массового спорта, что отчасти уже произошло. Процесс коммерциализации массового бега позволяет задать вопрос о расхождении дискурса власти (на развитие спорта) и реальной ситуации.

Ключевые слова: беговой бум, марафон, массовый спорт, кейс-стади, социология спорта, джентрификация спорта, коммерциализация спорта, управление спортом, фитнес-бум trajectory of the boom. "Entrepreneurs from running" were the consequence of the intial growth hence also contributing to the fitness boom. Their emergence is associated with the change of lobbying groups rather than with their opening of a "new niche". Side effects of entrepreneurship have emerged: gentrification of the run, its commercialization with an 18-fold increase in entry fees, thus reducing accessibility to participation. The study contributes to the discussion of sport models. We conclude that promoting "physical education for health" is pointless. We consider that the currently prevailing pro-Olympic model is the reason for low engagement of population into sports, and that it is dysfunctional for non-elite. We state that the introduction of an expressive model and repositioning of mass sports is needed (which in part has already happened). The process of commercialization of mass running raises the question about the discrepancy between the statements of the authorities (on the development of sports) and the real situation.

Keywords: running boom, fitness boom, marathon, mass participation sport, sociology of sport, commercialization of sport, sport policy, gentrification of sport 


\section{Модное увлечение молодых?}

«Бег трусцой из утреннего моциона пенсионеров превратился в модное увлечение молодых",- -утверждает недавняя статья в “Ведомостях" ${ }^{2}$. Действительно, статистика участия в крупнейшем российском пробеге (до 2012 г.- Московский международный марафон мира (ММММ), с 2013 г.-Московский марафон (ММ)) демонстрирует бурный рост в первой половине 2010-х годов, причем за счет притока молодежи. В чем причины и каковы драйверы этого бегового бума? Изменения позитивны или есть социальные издержки? Почему молодые прониклись увлечением "пенсионеров"?

Причины моды на бег и здоровый образ жизни (ЗОЖ) обсуждались в ряде публикаций прессы. Растущая популярность бега в 2014 г. была темой журналистских расследований, где феномен "моды на бег" увязывался с открытием бизнесом новой рыночной ниши. Объяснение причин роста указывало на предпринимателей-инициаторов "перезагрузки" главного марафона России, начавших работать с молодой аудиторией, и создавших в 2013 г. новые "более яркие" забеги серии ММ - якобы так была создана мода на бег и открыта пустовавшая прежде рыночная ниша ${ }^{2}$. Однако, несмотря на растущий в академическом сообществе интерес к теме 30Ж, фитнес-бум 2010-х почти не рассматривался в отечественной научной литературе. Таким образом, наше исследование (включая его более ранние варианты [Адельфинский, 2016, 2018]) - это, возможно, первая попытка его осмысления.

Цель данной статьи - через описание случая трансформации крупнейшего марафона России представить объяснение причин, драйверов и следствий бегового бума 2010-х годов. А также понять, как данная трансформация соотносится, во-первых, с проблемой противоречий олимпийского и массового сегментов спортивной отрасли и, во-вторых, с проблемой коммерциализации европейской модели спорта.

Структура работы выстроена согласно логике собранного материала. Результаты в целом описывают случай трансформации Московского марафона (из ММММ в ММ) и крупнейших серий беговых событий Москвы. После обзора литературы и гипотезы прессы следует описание выявленных факторов бегового бума 2010-х. Это наследие фитнес-бума 1970-1980-х, глобальная кампания по продвижению бега Nike, новые медиа, перемены во власти. Приведена динамика цен и возрастного профиля участников. Отмечены социальные издержки, включая 18-кратный рост взносов. В заключение дается общая интерпретация кейса.

\section{Обзор литературы}

Беговой бум 2010-х годов в отечественной научной литературе почти не рассматривался. До сих пор исследователи анализировали преимущественно физиологические параметры бегунов, методики тренировок, медицинское обеспечение забегов, труд волонтеров, элементы соответствующих рекламных кампаний и т.д.

\footnotetext{
1 Макушева М. Бегом за преодолением //Ведомости. 2020. 23 сентября. URL: http://vedomosti.ru/opinion/articles/ 2020/09/22/840853-begom-preodoleniem (дата обращения: 10.08.2021).

2 Мамедова Д. Все побежали. Кто и как зарабатывает на Московском марафоне? // Коммерсанть Секрет Фирмы. 2014. № 11. C. 30. URL: http://kommersant.ru/doc/2590706 (дата обращения: 10.08.2021).
} 
[Олефиренко, Буглак, Золотарева, Люлько, 2019; Пономарев, 2017; Рябкова, Кондрашова 2018; Слугин 2013; Климкович 2018; Михель, 2018]. Московский марафон упоминается лишь как подтверждение интереса поколения Ү к теме ЗОж [Аверина, 2019].

Зарубежные исследования социально-экономических аспектов массового бега сосредоточены преимущественно на собственных странах и России не касаются. Мы судим по недавней обзорной статье западноевропейских авторов [Scheerder, Breedveld, Borgers, 2015a] и списку цитирующих ее текстов. В ряде работ сообщается о возобновлении роста числа массовых пробегов и их финишеров после стагнации 1990-х годов, что рассматривается как свидетельство второй волны бегового бума на рубеже XX и XXI веков [Bezold, 2006; van Bottenburg, Hover, Scheerder, 2010; Scheerder, Breedveld, Borgers, 2015b; Hover, van der Werff, Breedveld, 2015; Nilson et al., 2021]. В данных работах изучались в основном характеристики беговой аудитории. Таким образом, речь шла скорее о следствиях, а не о причинах бума. В свою очередь, более ранее исследование о развитии Нью-Йоркского марафона П. Купер построено с опорой на концепцию "видимой руки" А. Чандлера-мл. [Cooper, 1992, 1998]. Мы намерены придерживаться того же подхода, то есть искать конкретные причины и акторов перемен.

\section{Дизайн и методы исследования}

Объектом нашего изучения выступает MMMM/MM, причем не как единичный марафон, а как крупнейшая серия пробегов в спортивном календаре Москвы 2000-х и 2010-х годов. В основу исследования положена стратегия изучения случая (кейс-стади). Авторы ряда обзорных работ подчеркивали гибкость данной стратегии, ее мультипарадигмальность, мультиметодичность, фрагментарность и разнообразие эмпирической базы, нарративную форму изложения результатов, а также ее холизм и контекстуальность [Полухина, 2013; Козина, Сережкина, 2015].

Для получения эмпирических данных мы использовали ряд методов. Во-первых, включенное наблюдение в циклических видах спорта, и начиная с 2003 г.в массовых забегах. Это позволило вести сбор фактов и неформально общаться со стейкхолдерами бегового “поля". Во-вторых, мы собирали и анализировали беговую статистику и документы - календари, протоколы и положения забегов, имеющиеся на ресурсе «ПроБЕГ в России и в мире» ${ }^{2}$. Нас интересовали: число участников, их профиль по возрасту и времени финиша, размер стартовых взносов, организаторы и локации беговых событий. В-третьих, мы анализировали уже опубликованные научные и публицистические статьи. В частности, запрос "московский марафон" к базе данных федеральной прессы "Интегрум" (http:// integrum.ru/) за 2010-2016 гг. выявляет 122 статьи; к базе данных РИНЦ (http:/ / elibrary.ru/) - 10 научных статей. Таким образом, возможная субъективность включенного наблюдения компенсируется тем, что второй и третий методы обеспечивают нас верифицируемой информацией с возможностью ее количественной оценки.

\footnotetext{
3 Ресурс «ПроБЕГ в России и в мире» был основан в 2003 г. группой бегунов-любителей как путеводитель по беговой жизни СНГ и де-факто является единственным источником статистики по массовому бегу РФ. Подробнее CM.: URL: http://probeg.org/ (дата обращения: 06.08.2021).
} 


\section{Версия прессы}

В 2014 г. журналисты изданий "Коммерсанть Секрет Фирмы” ${ }^{4}$, "РROcпорт» ${ }^{5}$ и "Огонек" 6 одинаково описывали причины бегового бума. "Бег стал модным явлением в столице, а предприниматель Дмитрий Тарасов - самым успешным организатором коммерческих забегов",- -утверждал "Коммерсанть Секрет Фирмы" ${ }^{7}$. Выясняя причины роста, журналистское расследование Д. Мамедовой указывало на открытие бизнесом новой рыночной ниши: "До недавнего времени <...> забеги организовывали <...> муниципалитеты или спортивные ассоциации. Все изменилось, когда новую нишу заметили предприниматели" ${ }^{8}$. Герой статьи - директор ММ и агентства "Новая атлетика" Д. Тарасов признался, что был вдохновлен бизнесстратегией "голубого океана" 9: “Зимой 2010-го <...> пришел к выводу, что коммерческие забеги - это и есть „голубой океан“. В России тогда никто не рассматривал бег как бизнес" ${ }^{10}$. Уже весной 2010 г., как сообщает "Коммерсанъь Секрет Фирмы», "не новичок в спортивном менеджменте <...> учредил [свое агентство] и познакомился с маркетинг-директором Nike в России. Тарасову повезло: стратегия [Nike] предусматривала расходы на продвижение товаров для бега и вовлечение в этот вид спорта новых участников" ${ }^{11}$. О бизнес-успехе ММ свидетельствовал анализ экономики проекта, а подтверждением общего успеха был новый всероссийский рекорд массовости участия на ММ против $\mathrm{MMMM}^{12}$.

Будущие "секреты производства" проекта ММ озвучивались при его анонсе в 2013 г.: "Аналогичные мероприятия уже проводятся в Лондоне, Париже, Токио, Нью-Йорке. В России же данный забег первый",- сообщала пресса в 2013 г., утверждая, что для любителей бега это “возможность принять участие в качественном мероприятии, которых так не хватает в России" ${ }^{13}$. Другое издание уточняло: «Первый Московский марафон - замена ММММ. Организовывает все по-прежнему правительство Москвы, только теперь им помогают новые люди, знающие толк в марафонах» ${ }^{14}$. Подчеркивались новинки ММ: «Впервые проведут пять подгото-

\footnotetext{
4 Мамедова Д. Все побежали: Кто и как зарабатывает на Московском марафоне? // Коммерсанть Секрет фирмы. 2014. № 11. C. 30. URL: http://kommersant.ru/doc/2590706 (дата обращения: 10.08.2021).

5 Калинина Н. Красота среди бегущих // PROспорт. 2014. №11. С. 134-137.

6 Беляев А. Бег снова в моде // Огонек. 2014. № 36. C. 44. URL: http://kommersant.ru/doc/2562549 (дата обращения: 10.08.2021).

7 Мамедова Д. Все побежали: Кто и как зарабатывает на Московском марафоне? // Коммерсанть Секрет фирмы. 2014. № 11. C. 30. URL: http://kommersant.ru/doc/2590706 (дата обращения: 10.08.2021).

8 Там же.

9 Речь о маркетинговой стратегии, описанной в книге У.Ч. Ким и Р. Моборн “Стратегия голубого океана: как создать свободную рыночную нишу и перестать бояться конкурентов" (М. : НІРPO, 2005).

10 Мамедова Д. Все побежали: Кто и как зарабатывает на Московском марафоне? // Коммерсанть Секрет фирмы. 2014. № 11. C. 30. URL: http://kommersant.ru/doc/2590706 (дата обращения: 10.08.2021).

11 Там же.

12 Там же.

13 Коган В. Бег днем и ночью. Московский марафон пройдет по главным улицам и бульварам столицы // Новые Известия. 2013. 4 апреля. №60. URL: http://newizv.ru/news/society/04-04-2013/180502-beg-dnem-i-nochju (дата обращения: 10.08.2021).

${ }^{14}$ Вяхорева В. Бег в Москве. Каким будет новый Московский марафон // Афиша Daily. 2013. 4 апреля. URL: https:// daily.afisha.ru/archive/gorod/archive/kakim-budet-novij-moskovskij-marafon/ (дата обращения: 10.08.2021).
} 
вительных [забегов]", онлайн-тайминг, уникальная трасса ${ }^{15}$. Активно отмечались недостатки замещаемого ММММ. Журналисты писали о ежегодном снижении его популярности: «Бегунов было человек 300, в основном старички 50-60 лет и старше. Молодежь марафон упорно игнорировала» ${ }^{16}$. Кроме Д. Тарасова, активно комментировала замену ММММ креативный директор ММ А. Боярская: "Московский марафон мира проходил 32 года подряд и был прекрасной традицией, которую нам совершенно не хотелось нарушать. Но с организацией были проблемы - оттенок советской культуры не в самых лучших проявлениях" ${ }^{17}$. Схожая позиция заявлена А. Боярской и в интервью 2016 г. На вопрос «Приходилось ли <...> встречаться с советской системой беговых клубов?» она отвечает: «Главное отличие в том, что советский спорт очень сильно ориентирован на результат. Если ты бегаешь иначе, не назло рекордам, то тебе не с нами <...>. В Москве существовал Международный марафон мира с адским дизайном и ужасной организацией. Это было жалкое зрелище: кругами по набережной бегали несколько сотен человек... Но при этом все приверженцы старой школы были убеждены, что все у них хорошо и ничего менять не надо <...>. В итоге мы с Тарасовым <...> ${ }^{18}$.

Итак, версия прессы вкратце такова: предприниматель создал привлекательный для молодой аудитории новый продукт участие в мероприятиях некоего “нового качества" - благодаря этому возникла "мода на бег" и открылась новая рыночная ниша. Возьмем эту версию как гипотезу и проведем кейс-стади, где отправной точкой будет "перезагрузка" крупнейшей серии пробегов России и появление "первого" Московского марафона.

Озвученная версия о предпринимателе вызывает ряд вопросов - о точности фактов и полноте их изложения; о наличии более широкого контекста происходивших событий; об уточнении "нового качества" забегов; о конкретизации "оттенков советской культуры". Те единичные статьи, противоречащие этой версии, обсудим ниже. Анализ же начнем с изучения вопроса о "советской системе беговых клубов", поставленного в процитированном выше интервью.

\section{Наследие фитнес-бума 1970-х и 1980-х}

Ориентированный на результат советский спорт как отрасль и советская "система" беговых клубов в реальности имели разный генезис и были антагонистами по сути. К концу советской эпохи функциональный смысл отечественной отрасли физической культуры и спорта (ФКиС) -спорткомитетов, федераций, добровольных спортивных обществ, секций и спортшкол - действительно свелся лишь к обеспечению высших достижений и результата на Олимпийских играх. "Все, даже формирование секций в самых глухих городах, выводится на решение головной задачи: рекорды, золотые медали",- писал Ю.П. Власов об институциональной

\footnotetext{
15 Там же.

${ }^{16}$ Бессребреников А. Новый марафон //Петровка, 38. № 33-34. 2013. 4-11 сентября. URL: http://petrovka-38. com/arkhiv/item/novyj-marafon (дата обращения: 10.08.2021).

17 Вяхорева В. Бег в Москве. Каким будет новый Московский марафон // Афиша Daily. 2013. 4 апреля. URL: https:// daily.afisha.ru/archive/gorod/archive/kakim-budet-novij-moskovskij-marafon/ (дата обращения: 10.08.2021).

18 Миронов Ф. Москва - город пьющий или бегающий? // Афиша Daily. 2016. 3 августа. URL: http://daily.afisha.ru/ cities/2499-kuda-pribezhala-moskvy-aktivisty-podvodyat-itogi-sportivnogo-buma/ (дата обращения: 10.08.2021).
} 
организации отрасли, сложившейся к концу 1970-х ${ }^{19}$. Но первопричиной виделась не абстрактная советская культура, а реальная практика международного олимпийского движения с его рекордистской (традиционно-состязательной, про-олимпийской) моделью, в логике которой цель участия в спорте - выиграть, победить, а сам спорт - пирамида отборочных соревнований с вершиной в виде олимпиады. В этой логике отрасль ФКиС развивалась в 1950-1960-х годах после вступления в олимпийское движение, что привело к утрате изначальной установки на массовость участия, сложившейся в 1920-х и 1930-х годах. А. А. Исаев отмечал, что хотя для массового спорта России проблема негативного влияния реального олимпизма приобрела наиболее острый характер, она свойственна также и для западных стран [Исаев, 2002].

Советские клубы любителей бега и лыж (КЛБ и ЛК) возникли уже как часть нового глобального феномена, не укладывавшегося в олимпийскую модель. Феномен получил разные названия: программа "Спорт для всех", ЗОЖ, фитнес- и беговой бум и т. п. По сути, речь шла об иной, экспрессивной модели спорта. В 1970-х и 1980-х годах этот “спорт для всех" обрел форму открытых соревнований по бегу, триатлону, лыжам, велоспорту и т. п., отличительной чертой которых стал открытый допуск без селекции по мастерству или возрасту, а также демократичные временнб́е лимиты. Если в рекордистской модели цель участия - победить соперника, то в экспрессивной победа может трактоваться иначе - как свой результат, свое достижение, победа над собой, над дистанцией или обстоятельствами. Это создает цель участия для ординарных атлетов (то есть для всех желающих), чья карьера развивается не от значка ГТО к олимпийской медали, но от 5 км - к марафонам, триатлонам и многодневным гонкам на базе календаря подобных событий. Эксперты рекомендовали занимающимся выстраивание календаря из 24 стартов в год, участие в которых придает осязаемый смысл регулярным тренировкам. Спортивный календарь наполняется индивидуально: любители со стажем способны бегать полумарафоны еженедельно, новичкам предлагают готовиться к 5 км не менее двух месяцев [Адельфинский, 2014, 2021].

Первые советские КЛБ возникли в 1970-х годах. В основном это была самодеятельная активность любителей бега, лыжного спорта и т. п., создававших подобные открытые соревнования для самих себя. Бурный рост начался в 1980-х: движение КЛБ и ЛК обрело скромную поддержку власти - подобные клубы стали создаваться при предприятиях. В газете "Советский спорт" и журнале "Легкая атлетика" возникли рубрики КЛБ/ЗОЖ, был учрежден ряд массовых мероприятий. Пробег "Труд" из состязания элитных стайеров трансформировался в открытое событие. В 1981 г. был основан Московский международный марафон мира, ставший ведущим советским пробегом. К началу 1990-х движение КЛБ заметно выросло, но для отрасли ФКиС этот феномен так и остался периферийным элементом, с уничижительным отношением как к "массовке" со стороны спортивных работников. Эксперты ратовали за независимое системное развитие "спорта для всех" как новой формы, чего, однако так и не произошло [Чернов, Кузнецов, Каширцев, 1992].

\footnotetext{
${ }^{19}$ Власов Ю.П. Зачем нам нужен спорт? // Советская культура. 1988. 23 апреля. С. 8.
} 
Рис. 1. Число финишеров крупнейшего пробега России, ММММ/ММ 42 км

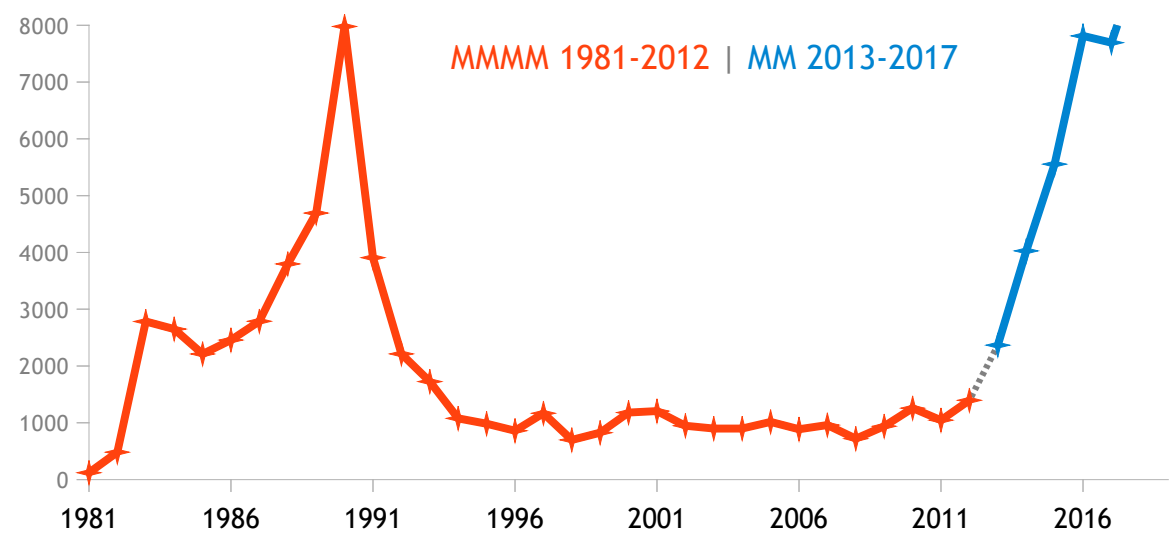

Мы полагаем, что причины спада отечественного фитнес-бума вызваны издержками трансформации экономики в 1990-х годах. Причем система ФКиС сохранилась, по сути, неизменной, имея бюджетную привязку. Напротив, большинство КЛБ прекратили существование вслед за реформой предприятий и секвестром социальных программ. Отдельные клубы сумели выжить на энтузиазме их членов в основном как малые группы. Также сохранился ряд массовых мероприятий, имевших поддержку городских властей. В частности, в Москве это крупнейшие серии пробегов - ММММ и «Труд-Лужники". Число финишеров ММММ на дистанции 42,195 км хорошо отражает динамику бегового бума СССР и России в целом - рост в 1980-х, а затем резкий спад в 1991-1993 гг. до некого уровня, остававшегося стабильным (см. рис. 1). Почему же вовлечения новых участников удалось добиться лишь в 2010-х? Полагаем, ключевой причиной стала успешная рекламная кампания по продвижению бега, а вовсе не открытие "голубого океана" предпринимателями.

\section{Транснациональная кампания Nike по продвижению бега в 2000-х и 2010-х}

"События удивительные стали происходить в беговом мире Москвы,- записал в дневнике сооснователь ресурса Probeg.org Владимир Метелкин.—Сначала компания Nike начала двигаться в сторону бегунов, разродившись... серией! Но вот сдвинулся с места великий спортивный монстр Adidas! На 25.09.2010, в субботу, Adidas Challenge - на день раньше Nike Run. Что-то будет?» ${ }^{20}$ Описываемые события - запуск московский кампании по продвижению субкультуры бега, ранее развернутой фирмой Nike на развитых рынках. В 2003-2005 гг. кампания проводилась в ряде городов Северной Америки как Nike Run Hit Wonder, в 20082009 гг.-уже в 27 городах мира как Nike + Human Race, а начиная с 2010 г.-

\footnotetext{
${ }^{20}$ Метелкин B. Adidas Challenge, 4.1км 19.50//Блог факультативных занятий спортом. 2010. 25 сентября. URL: http://wld-archiv2007-2013.blogspot.com/ (дата обращения: 10.08.2021).
} 
на растущих рынках как Nike We Run ${ }^{21}$. Ее ключевыми элементами стали типовая ивент-программа и некое креативное решение с героем как ролевой моделью.

Героем кампании Nike Run в Торонто в 2003 г. стал начинающий бегун, молодой мужчина не в лучшей форме, но настроенный финишировать в Nike Run, даже если умрет. В течение 9 недель он рассказывал о своей подготовке к 10-километровому пробегу, приглашая желающих присоединиться. В качестве средств медиапродвижения использовались утреннее шоу на радио, колонка в бесплатной газете и наружная реклама. Целью кампании было вдохновить среднего горожанина встать с дивана, сподвигнув городское сообщество к разговорам о бегунах, нынешних и будущих. А также, конечно, привести на сайт или в точки продаж компании для регистрации на забег Nike Run 10 км, создав тесную связь между продукцией Nike и событием. Кампания увенчалась успехом, собрав более 7500 бегунов, а также сделав ее героя городской знаменитостью ${ }^{22}$.

Ивент-программа - вторая, более типовая часть беговых кампаний Nike, которую, очевидно, обеспечивают учреждаемые агентства-подрядчики. Так, агентство Lulu Live было создано для организации мероприятий Nike Run Hit Wonder в 2003 г. на Северо-Западе США с целью представить бег новой аудитории свежим способом, создав преимущества для бренда Nike. Эта цель реализовывалась путем организации программ 7-недельных бесплатных тренировок с кульминацией в виде 5- и 10-километровых массовых пробегов с концертным оформлением. Роль агентства заключалась в контроле и управлении субподрядчиками, планировании и реализации всех элементов событий, оперируя для этого бюджетом ивент-программы ${ }^{23}$. Де-факто агентство было менеджером проекта, оформленным в качестве независимой фирмы.

\section{Российская адаптация кампании: Nike Run Moscow в 2010-2015 гr.}

Кампания Nike We Run в Москве стартовала весной 2010 г. Рекламные постеры в столичных вузах предлагали вступить в движение "Я бегу", примкнув к соответствующей группе во "ВКонтакте». Группа информировала о тренировках, маршрутах и забегах проекта. Дважды в неделю в десяти парках все желающие занимались "под руководством профессиональных тренеров" ${ }^{24}$. Информацию подтверждает дневник В. Метелкина: «С положительными эмоциями узнал <...> что Nike решила вложить деньги в развитие любительского бега <...> продюсировав проект „Я бегу“, наняв инструкторами десяток вчерашних студентов <...> [ставших]

\footnotetext{
${ }^{21}$ Подробнее см.: Nike Run Hit Wonder Race Returns for 2005 National Tour // Nike.com. 2005. June 7. URL: http://news. nike.com/news/nike-run-hit-wonder-race-returns-for-2005-national-tour (дата обращения: 10.08.2021); Runners Unite for Nike+ Human Race 2009 // Nike.com. 2009. October 24. URL: http://news.nike.com/news/runners-unite-for-nikehuman-race-2009 (дата обращения: 10.08.2021); We Run Photo Gallery // Nike.com. 2012. August 13. URL: https:// news.nike.com/news/we-run-2011-photo-gallery (дата обращения: 10.08.2021).

${ }^{22}$ Billiam J. Nike's "Running Guy" Comes to Life on Radio // JamesGang.com. 2007. URL: https://www.jamesgang.com/ billiam/nikerunning2007.pdf (дата обращения: 10.08.2021).

${ }^{23}$ Stevens G. L. Nike Run Hit Wonder 2004 //LuLuLive.net. 2008. URL: http://lululive.net/experience/detail.php?c= 2410899 (дата обращения: 10.08.2021).

${ }^{24}$ Кампания для Nike продолжилась “забегом в отрыв" //Sostav.ru. 2010. 16 августа. URL: http://sostav.ru/news/ 2010/08/16/cod4/ (дата обращения: 10.08.2021).
} 
проводить занятия среди начинающих" ${ }^{25}$. Управляло ивент-программой новоучрежденное агентство-подрядчик "Новая атлетика» (то есть Д. Тарасов), его сайт NewRunners.ru публиковал пресс-релизы забегов. O главном пробеге Nike Run Moscow 2010 можно найти массу отчетов: «Задача участников <...> пробежать $<\ldots>5$ км <...>. После награждения всех <..> ждал главный приз - праздничный концерт <...> Cheese People, Run Run Run и <...> Софи Эллис-Бекстор” ${ }^{26}$.

Героем московской кампании Nike в 2011 г. стала 25-летняя журналистка, модель и актриса Александра Боярская-Уэйт, автор блога о жизни в Лондоне. Ранее не занимаясь бегом, в июне 2011 г. она начала первые регулярные пробежки. Медиасредства кампании: новый блог NikeMarathon ${ }^{27}$, группы в соцсетях, ряд изданий. За месяц до Nike Run Moscow 2011 в одной из статей всем желающим предложили бежать его вместе с Боярской, рассказав о девушке, которая уже два месяца "удивляет френдленту <...> не только заметками о <..> лондонской жизни, но и отчетами о беговых тренировках", готовится бежать 21,1 км на Nike Women's Marathon в Сан-Франциско, "искренне повествуя о радостях и трудностях на пути» ${ }^{28}$. Предисловие статьи подчеркивает рекламный месседж: "Скорее бег фигурирует в текстах, как способ по-новому посмотреть на город, на отношения с другими <...> и самим собой ${ }^{29}$. В статье можно увидеть и ролевую модель: "Среднестатистический бегун в Лондоне - девушка или молодой человек лет 30-35, бегает два или три раза в неделю в парке вечером <...> по 4-5 миль; иногда принимает участие в соревнованиях на 5, 10 или полумарафонские дистанции [21,1 км]..." 30

«В парке Горького откроется беговой клуб принципиально нового типа» ${ }^{31}$,- сообщала пресса в апреле 2012 г. Созданный Nike клуб располагал станцией для переодевания и хранения вещей и был бесплатным. Как и ранее, предлагалось участвовать в тренировках к финальному забегу на 10 км. Уже в мае инсайдеры рассказывали об очевидном успехе клуба и проекта в целом: "[На тренировку] собралось больше пятидесяти человек, а в первый сезон начинали семь или десять" ${ }^{32}$. Идентичные станции возникли в Филях и Сокольниках.

Московская кампания Nike We Run продолжалась с 2010 по 2015 гг., модифицируясь по мере развития. Она подразумевала организацию не одного старта, а регулярные тренировки и участие в серии забегов. Например, в 2012 г. серия началась 15 июля с пробега на 3 км (Level 1: Run for likes), 12 августа - уже на 5 км (Level 2: Величие в каждом), 26 августа - на 7 км (Level 3: Get ready)

\footnotetext{
${ }_{25}$ Метелкин B. Day Run (Nike), 5 км =17.43 SB // Блог факультативных занятий спортом. 2010. 28 aвгуста. URL: http:// wld-archiv2007-2013.blogspot.com/ (дата обращения: 10.08.2021).

${ }^{26}$ Воронина А. МГТУ МАМИ на Run Moscow 2010 // Автомеханик. 2010. № 8 (68). С. 5.

${ }_{27}$ Waitt A. Блог Ready, Steady, Go! URL: http://nikemarathon-blog.tumblr.com/ (дата обращения: 10.08.2021).

${ }^{28}$ Меньше слов, больше бега: Александра Боярская-Уэйтт о беге //Look At Me. 2011. 18 авгуcта. URL: http:// lookatme.ru/flow/posts/nike/133739-menshe-slov-bolshe-bega-aleksandra-boyarskaya-ueytt-o-bege (дата обращения: 10.08.2021).

${ }^{29}$ Там же.

зо Там же.

${ }_{31}$ Рагоза Д. В парке Горького откроется беговой клуб принципиально нового типа // Москва-онлайн. 2012. 18 апреля. URL: http://molnet.ru/mos/ru/culture/o_46190 (дата обращения: 10.08.2021).

32 Там же.
} 
и затем 16 сентября - финальный пробег на 10 км (собственно Nike Run Moscow). Подобное регулярное участие и составляет практику бега, но отличием схемы Nike стал фокус на начинающих. Активная рекламная и PR поддержка наблюдалась в 2010-2012 гг. под разными названиями: “Беги в отрыв" в 2010 г., "Меньше слов, больше бега" в 2011 г., “Ты против себя" в 2012 г. Затраты Nike лишь на наружную рекламу в эти годы суммарно оцениваются в 13,8 млн руб., или 480 тыс. долл., по данным мониторинга ЭСПАР (http:/ /espar.ru). Как видим, кампания Nike в Москве была локальной адаптацией глобальной кампании. Отметим, что в публикациях об истории успеха ММ его предыстория (то есть западные и российские кампании Nike) почти не упомянута. В лучшем случае о ней говорится косвенно, строкой или парой слов, как о части биографии директора ММ, характеризующей его как эксперта (будто бы его познания просветили корпорацию Nike).

\section{Изменения коммуникационной среды}

Трансформация медиасреды - следующее значимый фактор бегового бума. В 1980-е годы важную роль для продвижения массового бега и для самих любителей бега и триатлона играла рубрика КЛБ/ЗОЖ газеты “Советский спорт». Схожая рубрика поддерживалась в журнале “Легкая атлетика", официальном издании Госкомспорта СССР и профильной федерации. Однако уже в 1990-е годы число клубов и активных атлетов-любителей заметно снизилось. Упала покупательская способность населения и тиражи ведущих изданий. "Советский спорт» и “Легкая атлетика" сузили тематику, уйдя от массовости к мастерству. С середины 1990-х годов регулярно освещать тему массового бега, в частности публиковать календарь марафонов и пробегов, начал журнал “Бег и мы” Б. Прокопьева. Однако, несмотря на ценность этого издания для целевой аудитории, его влияние сложно сравнить с широковещательным эффектом "Советского спорта", одной из ведущих газет СССР с тиражом более четырех миллионов экземпляров. Субкультура бега отчасти замкнулась внутри себя.

В 2000-х годах все большую значимость начала обретать новая коммуникационная среда - интернет. В 1998 г. число ее российских пользователей составляло всего 1,5 млн человек. В 2004 г. проникновение интернета выросло до 15 \% населения РФ, а к 2013 г.-уже до $60 \%$. Таким образом, появился простой способ распространения информации, благодаря которому в 2004 г. всего одному волонтеру (автору статьи) удалось запустить успешную кампанию по продвижению триатлона при нулевом бюджете ${ }^{33}$. Для массового бега в 2003 г. важным событием стало появление ресурса Probeg.org, ставшего публиковать календарь пробегов в России и СНГ и вести статистику бегового движения. В 2000-х годах сайт поддерживался на волонтерских началах группой всего из пяти бегунов-любителей.

В 2010-х годах рост числа смартфонов и соцсетей изменил взаимодействие аудитории с медиасредой. Если ранее новый бегун-любитель был проактивен, то есть искал информацию сам, то теперь возможность участия "открывалась" через новостные ленты соцсетей. Новое поколение бегунов в 2012 г. рассказывало похожие истории: “Случайно увидела в социальной сети, что подруга бегает»;

\footnotetext{
${ }_{33}$ Шахматов А. Ветеранское и любительское движение //Триатлон. 2011. № 1. С. 50—54. URL: http://federalbook. ru/files/ARHIV/Triatlon/triatlon-magazin.pdf (дата обращения: 10.08.2021).
} 
"Просматривал френдленту „ВКонтакте“, узнал, что приятель занялся»; “Листал Facebook, наткнулся на статью» ${ }^{34}$. Бренд-директор Nike Russia М. Джинко сообщил, что успех Nike Run Moscow 2012 был достигнут "во многом благодаря социальным сетям и сарафанному радио» ${ }^{35}$.

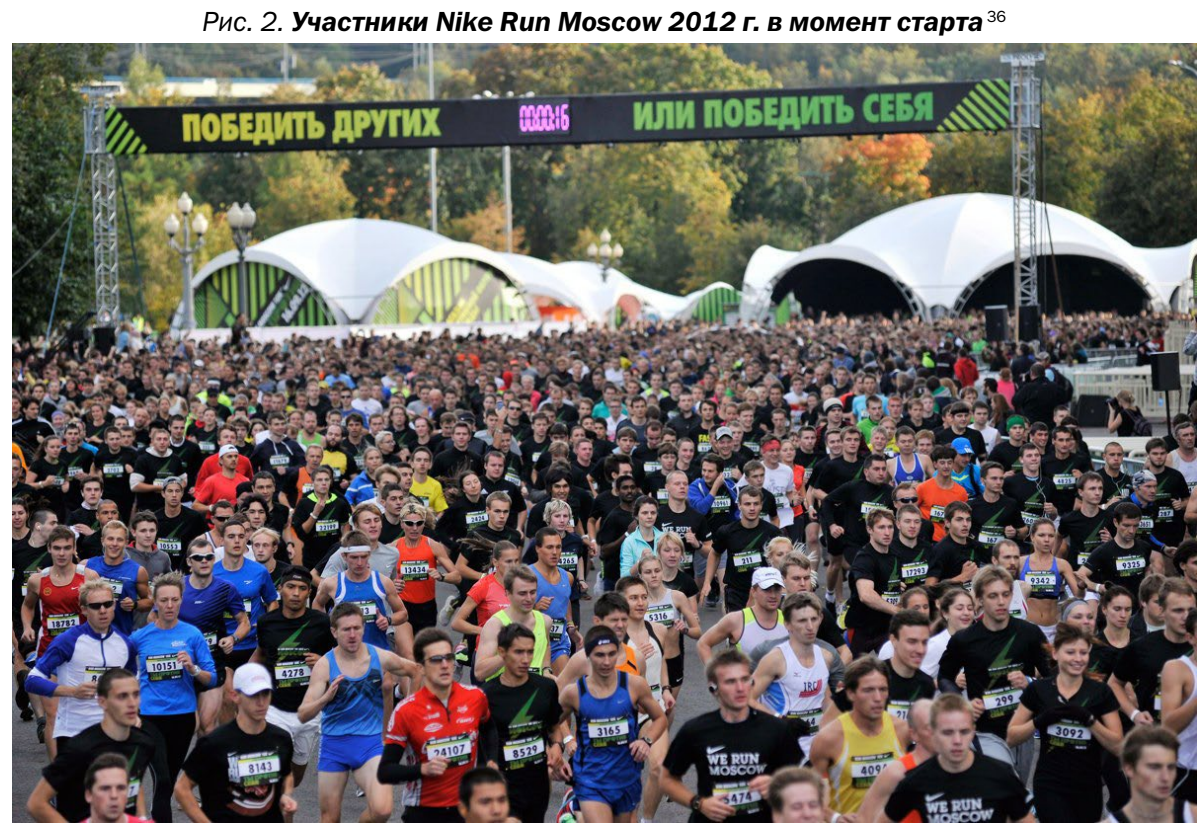

Параллельно собственную программу продвижения бега реализовывал бренд Adidas. Компания провела пробеги Adidas Challenge 2010 (дистанция 3 км и 5 км; 292 финишера), Adidas Moscow Half Marathon 2011 (10 км и 21,1 км; 916 финишеров), Adidas Energy Run 2013 и Adidas Run High! 2015. Первая беговая станция Adidas возникла в 2013 г. на площадке "Лужники" и затем еще в ряде парков. В 2015 г. была проведена кампания "Разбуди район» 37.

Эффективность кампаний по вовлечению новой аудитории в практику бега можно оценить по числу финишеров Nike Run Moscow, а качество вовлечения по деталям из заметок В. Метелкина. Если в 2011 г. "добежало до финиша по любой траектории" в забеге на 10 км 1526 человек и на 5 км - 4890 человек, то в 2012 г. «пробежало, нигде не срезав", дистанцию 10 км -уже 9125 человек ${ }^{38}$.

\footnotetext{
34 Подробности включенного наблюдения изложены в другой статье [Adelfinsky, 2021].

35 Зарубежные спикеры: Massimo Giunco, Массимо Джинко, директор по развитию бренда компании Nike Russia. См.: [Лекция в рамках программы Менеджмент в игровых видах спорта RMA] //RMA.ru. 2012. 15 ноября. URL: http:// rma.ru/sport/foreign_speakers.php/15718/ (дата обращения: 10.08.2021).

${ }^{36}$ Источник: сайт ПроБЕГ. URL: http://probeg.org/new/img/1347872633_1.jpeg (дата обращения: 10.08.2021).

37 “Разбуди свой спальный район”: как Adidas и TBWAMoscow меняли взгляды москвичей на бег // ADVERtology. Hayка о рекламе. 2015. 1 декабря. URL: http://www.advertology.ru/article134434.htm (дата обращения: 10.08.2021).

${ }^{38}$ Метелкин B. III Nike Run Moscow, 10km = 35.24 РВ // Блог факультативных занятий спортом. 2012. 16 сентября. URL: http://wld-archiv2007-2013.blogspot.com/ (дата обращения: 10.08.2021).
} 
Для сравнения: в 2000-е годы крупнейший регулярный пробег на 10 км (забегспутник ММMM) собирал порядка 1,2-1,6 тыс. человек (см. табл. 1). Можно констатировать, что успех был достигнут уже к 2012 г., еще до предпринимателя Тарасова с его идеей "коммерческих забегов" (см. рис. 2). Подчеркнем, что забеги Nike и Adidas в 2010-2015 гг., а также тренировки для подготовки к ним были бесплатны.

Таблица 1. Пробеги Nike Run Moscow ${ }^{39}$ и MMMM/MM, 2007-2014 гr.

\begin{tabular}{|l|c|c|c|c|c|c|c|c|}
\hline Кол-во финишеров/Год & $\mathbf{2 0 0 7}$ & $\mathbf{2 0 0 8}$ & $\mathbf{2 0 0 9}$ & $\mathbf{2 0 1 0}$ & $\mathbf{2 0 1 1}$ & $\mathbf{2 0 1 2}$ & $\mathbf{2 0 1 3}$ & $\mathbf{2 0 1 4}$ \\
\hline Nike Run Moscow 10 км & - & - & - & - & 1526 & 9125 & 8947 & 8328 \\
\hline Nike Run Moscow 5 км & - & - & - & н.д.* & 4890 & - & - & - \\
\hline $\begin{array}{l}\text { Nike Run Moscow, } \\
\text { принято заявок }\end{array}$ & - & - & - & 12000 & 17000 & 22000 & Н.д. & н.д. \\
\hline ММММ І ММ 10 км & 1161 & 1025 & 1569 & 1459 & 1398 & 1743 & 2412 & 5302 \\
\hline ММММ І ММ 42 км & 778 & 719 & 854 & 1136 & 981 & 1214 & 2367 & 4031 \\
\hline
\end{tabular}

* Нет данных по числу заявок или участников.

\section{Конъюнктура власти и метаморфоза крупнейших забегов Москвы}

Изменения в политической конъюнктуре также оказались значимым фактором и для кампаний по продвижению бега, и для появления якобы "первого в России" марафона. В марте-апреле 2011 г. произошло обновление топ-менеджмента в Правительстве Москвы и аффилированных структурах. Департамент культуры Москвы возглавил С. Капков (взамен С. Худякова), Департамент физической культуры и спорта - А. Воробьев (взамен М. Степанянца), Спортивный комплекс "Лужники" А. Пронин (взамен В. Алешина). Обновление крупнейших парков Москвы и введение бесплатного входа превратило их в элементы культуры досуга 2010-х. Частью реформы парков стало появление беговых станций Nike, где тренировки в рекордные дни собирали уже до 200 атлетов. На эту связь прямо указывает А. Боярская: «Катя Кибовская из дирекции <...> увидела [мой блог] <..> и пригласила <...> делать беговой клуб<...> роль реформатора сыграл Капков <...> [они] - причина того, что туристический центр Москвы сместился <...> в Парк культуры" ${ }^{40}$.

Другое явное следствие перемен во власти - изменение бегового "поля" ${ }^{41}$ Москвы в 2012-2013 гг. Двух организаторов крупнейших серий пробегов Москвы, В. Шиханова (1939 года рождения) и Б. Фадеева (1933 года рождения), последовательно замещает один - Д. Тарасов (1977 года рождения). Вначале, в 2012 г. Тарасов со своим агентством "Новая Атлетика" стал организатором серии забегов “Труд-Лужники» ${ }^{42}$, сменив директора АНО «Лужники Олимп» В. Шиханова.

\footnotetext{
39 Источник: заметки В. Метелкина, а также Радкевич А. Статистика бегового движения в России // Личный блог А. Радкевича. 2015. 7 мая. URL: http://akmych.org/blog/753 (дата обращения: 10.08.2021).

40 Миронов Ф. Александра Боярская о беге, комбинации пива с крепким и конце закрытых сообществ // Афиша Daily. 2013. 23 октября. URL: http://daily.afisha.ru/archive/gorod/changes/aleksandra-boyarskaya-o-bege-kombinacii-pivas-krepkim-i-konce-zakrytyh-soobshchestv/ (дата обращения: 10.08.2021).

41 Речь о совокупности беговых соревнований, где термин «поле» более приемлем, нежели “рынок".

42 Серию "Труд-Лужники" составляли “Марафон Лужники", «Пробег Труд", «Пробег Россия", "Беги и улыбайся".
} 
Секрет омоложения кадров раскрыт в статье "Коммерсанта»: "Александр Пронин $<\ldots>$ хотел реанимировать марафон „Лужники“. Тарасов <...> убеждал <...> что нет смысла перекрывать центр города ради 300 дедушек, которые воспринимают марафон как советскую традицию здорового образа жизни" ${ }^{43}$. Тарасов предложил новому директору комплекса "Лужники" вовлекать молодежь и делать шоу-мероприятие, “организовал интернет-регистрацию <...> и начал работу с соцсетями" ${ }^{44}$. Общее число участников "Марафона Лужники" выросло с 600 человек в 2011 г. до 1041 в 2012 г. Мы полагаем, задача привлечения новой аудитории решилась благодаря "переливу" клиентской базы Nike Run Moscow, что и обеспечило дальнейший административный успех для Тарасова.

В 2013 г., когда пресса объявила “первый в России марафон" и то, что “Впервые проведут пять подготовительных забегов" ${ }^{45},-$ по сути, не возникло новых беговых событий вообще. Де-факто Д. Тарасов, уже управляя целой серией забегов и “Марафоном Лужники», лишь заместил конкурента за административный ресурс - главу АНО “Фонд ММММ» Б. Фадеева ${ }^{46}$. Мы полагаем, созданный Nike подрядчик решил стать единственным подрядчиком по организации крупнейших забегов для города Москвы, “подвинув" прежних игроков (см. табл. 2). Впрочем, что привело для Тарасова к прекращению работы с Nike. Важны детали: площадкой Nike Run Moscow в 2011-2012 гг. служил комплекс "Лужники»; и в апреле 2013 г. первый МM презентовала А. Боярская - посол Nike. Однако летом 2013 г. компания Adidas (прямой конкурент Nike) была объявлена спонсором ММ. В сентябре якобы “первый в России" марафон стартовал с территории “Лужников" по центру города, a Nike Run Moscow переместился на периферийную территорию ВДНХ.

Таблица 2. Трансформация крупнейших беговых серий Москвы: 2011 vs 2013-2014

\begin{tabular}{|c|c|c|}
\hline $\begin{array}{l}\text { Серии ММММ и “Лужников", } \\
2011\end{array}$ & $\begin{array}{c}\text { Серия ММ “Новой Атлетики”, } \\
2013\end{array}$ & $\begin{array}{c}\text { Серия ММ «Новой Атлетики”, } \\
2014\end{array}$ \\
\hline $\begin{array}{c}\text { XIX ММпМ } \\
\text { 10/21 км (14 мая) }\end{array}$ & $\begin{array}{l}\text { I Первый забег } \\
5 \text { км (7 апреля) }\end{array}$ & $\begin{array}{l}\text { II Первый забег } \\
5 \text { км (6 апреля) }\end{array}$ \\
\hline $\begin{array}{l}\text { XV Марафон Лужники } \\
\text { 10/42 км (22 мая) }\end{array}$ & $\begin{array}{l}\text { III Весенний гром } \\
\text { 10/21 км (12 мая) }\end{array}$ & $\begin{array}{c}\text { I Московский полумарафон } \\
\text { 10/21 км (18 мая) }\end{array}$ \\
\hline $\begin{array}{c}\text { LXI Пробег Труд } \\
\text { 5/21 км (25 июня) }\end{array}$ & $\begin{array}{l}\text { I Ночной забег } \\
10 \text { км (22 июня) }\end{array}$ & $\begin{array}{l}\text { II Ночной забег } \\
10 \text { км (26 июля) }\end{array}$ \\
\hline $\begin{array}{l}\text { XVI Пробег Россия } \\
15 \text { км (6 августа) }\end{array}$ & $\begin{array}{c}\text { IV Осенний гром } \\
\text { 10/21 км (4 августа) }\end{array}$ & $\begin{array}{c}\text { I Музыкальный полумарафон } \\
\text { 10/21 км (17 августа) }\end{array}$ \\
\hline $\begin{array}{c}\text { XVII Беги и улыбайся } \\
6 \text { км (3 сентября) }\end{array}$ & $\begin{array}{l}\text { I Красочный забег } \\
6 \text { км (25 августа) }\end{array}$ & $\begin{array}{l}\text { II Красочный забег } \\
6 \text { км (21 июня) }\end{array}$ \\
\hline $\begin{array}{c}\text { XXXI МММM } \\
\text { 10/42 км (18 сентября) }\end{array}$ & $\begin{array}{c}\text { I MM } \\
\text { 10/42 км (15 сентября) }\end{array}$ & $\begin{array}{c}\text { II МM } \\
10 / 42 \text { км (21 сентября) }\end{array}$ \\
\hline
\end{tabular}

\footnotetext{
${ }_{43}$ Мамедова Д. Все побежали: Кто и как зарабатывает на Московском марафоне? // Коммерсанть Секрет фирмы. 2014. № 11. C. 30. URL: http://kommersant.ru/doc/2590706 (дата обращения: 10.08.2021).

44 Там же.

${ }^{45}$ Вяхорева В. Бег в Москве. Каким будет новый Московский марафон // Афиша Daily. 2013. 4 aпреля. URL: https:// daily.afisha.ru/archive/gorod/archive/kakim-budet-novij-moskovskij-marafon/ (дата обращения: 10.08.2021).

46 Основу серии АНО “Фонд ММММ» составляли ММММ и ММпМ (Московский Международный полумарафон мира).
} 


\section{Беговая статистика: возрастной состав и стоимость участия}

Перераспределение административного ресурса трансформировало беговое "поле». В 2011 г. пробеги двух серий (“Труд-Лужники" и ММММ) обеспечили 41\% всех человеко-участий на массовых пробегах Москвы. В 2016 г. пробеги уже одной серии $\mathrm{MM}-65 \%{ }^{47}$. Причем утверждения про “300 дедушек” и “акцент на результат" для прежних пробегов явно некорректны (см. рис. 3 и рис. 4). В 2011 г. на двух дистанциях ММММ стартовало 2650 атлетов от 15 до 85 лет, средний возраст и время финиша на марафоне - 40 лет и 3 часа 59 минут, лимит времени - 6 часов. Аналогичные числа характерны и для западных марафонов.

Рис. З. Рост и омоложение крупнейшего пробега России, ММММ/ММ 42 км

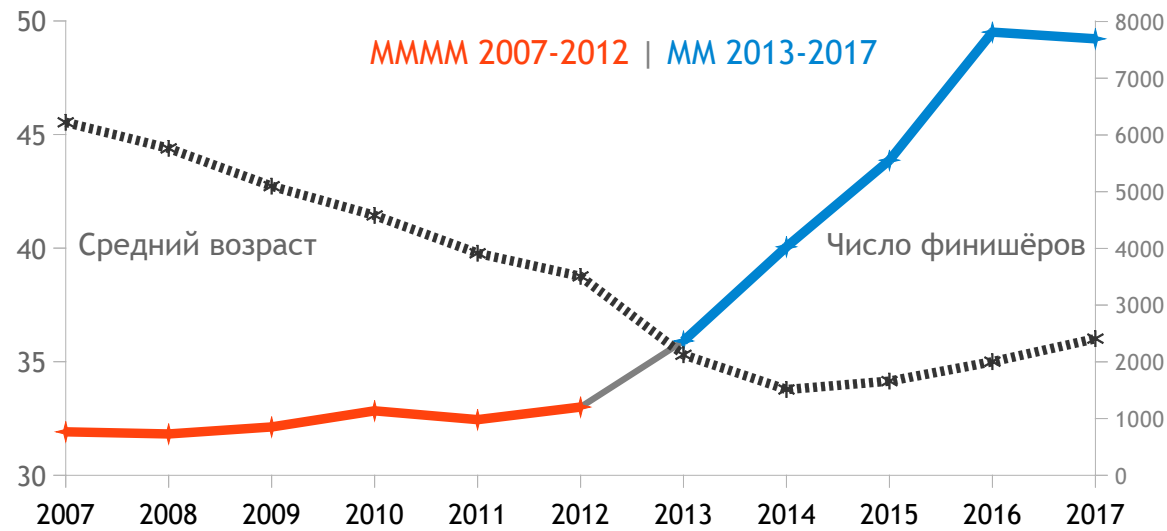

Рис. 4. Изменение возрастного профиля ММММ/ММ, 42 км: 2007 vs 2012 vs 2017

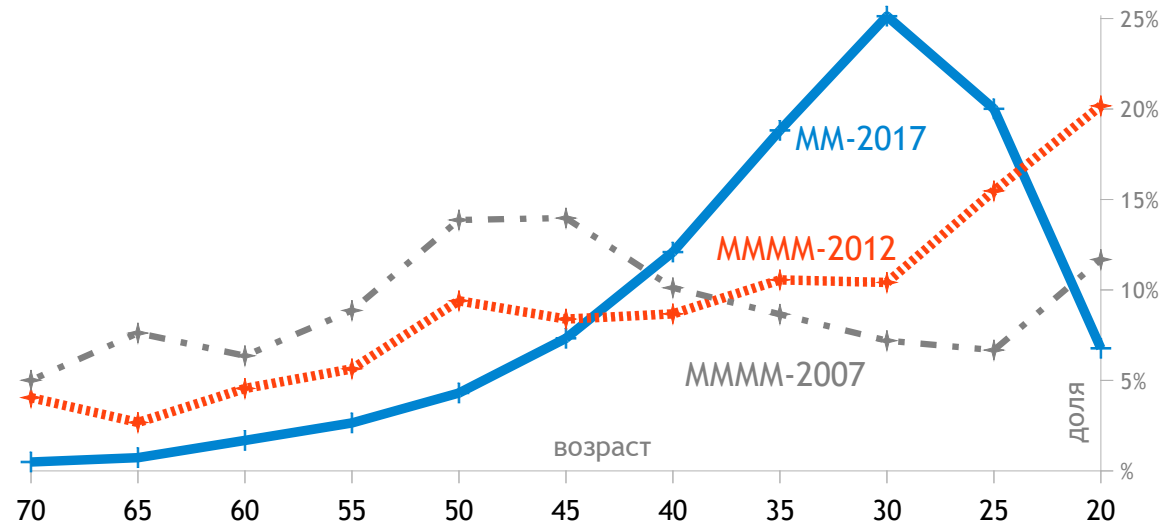

\footnotetext{
47 Мы учли пробеги со 100 финишерами и более на дистанциях от 6 до 42 км, упомянутые Probeg.org. В 2011 г. состоялось 10596 человеко-участий, в 2016 г.-53 063.
} 
Что касается возрастного профиля, то ММММ 2007 также похож на западные марафоны с той поправкой, что пик участия сдвинут на пять лет к более старшей аудитории. (Как пример можно взять Берлинский марафон.) Однако на ММММ 2012 пик участия приходится уже на 20-29-летних.

С течением времени возросло не только число бегающих, но и стартовые взносы. В 2011-2012 гг. взносы серии ММММ за дистанции 10 км и 21,1 км составляли 100 руб. и 150 руб. соответственно, за марафон - 250-300 руб. в зависимости от времени оплаты. Серия ММ «Новой атлетики» подняла диапазон цен вначале до 500-2000 руб., а затем, в 2016 г., уже до 1000-4000 руб. (см. табл. 3). Поскольку любители бега стартуют не разово, а зачастую еженедельно, можно оценить величину стоимости регулярного участия. Трансформация крупнейших беговых серий повлияла на все беговое «поле", где взносы выросли до уровня ММ. Это позволяет использовать цены ММ для расчета общей стоимости участия в практике бега. Оценка стоимости 24 стартов в год (по плану $15 \times 10$ км, $7 \times 21$ км и $2 \times 42$ км $)^{48}$ демонстрирует рост с 2950-3050 руб. до 29500-55500 руб. Таким образом, стоимость увлечения бегом за пять лет выросла в 10-18 раз. При этом МРОТ г. Москвы как показатель стоимости жизни вырос лишь в 1,6 раза.

Таблица З. Рост стоимости участия в ММММ-ММ с 2011 по 2016 гг. (взнос, руб.)

\begin{tabular}{|c|c|c|c|c|}
\hline Дистанция & МММм 2011-2012 & Мм 2013-2014 & MM 2015 & МM 2016 \\
\hline 10 км & 100 & $1000 / 750 / 500$ & $1500 / 1100 / 700$ & $2000 / 1500 / 1000$ \\
\hline 21 км & 150 & $1000 / 750 / 500$ & $1500 / 1100$ & $2500 / 2000 / 1500$ \\
\hline 42 км & $250 / 200$ & $2000 / 1300 / 1000$ & $3000 / 1800 / 1200$ & $4000 / 3000 / 2000$ \\
\hline За 24 гонки & $2950 / 3050$ & & & $29500 / 55500$ \\
\hline
\end{tabular}

\section{Дискуссия о “новом качестве"}

Порожден ли беговой бум неким "новым качеством" Московского марафона? Полагаем, качественные изменения коснулись лишь механизма заявки на пробеги, оплаты взноса и технологии учета времени. Благодаря внедрению IT-решений предварительные результаты соревнований стали быстрее появляться онлайн. Также медали финишера стали чуть больше. При этом форма оплаты и рост суммы взносов снизили потребительскую и экономическую доступность бега.

Изменились ли качественно впечатления от процесса участия в "новых" забегах? Полагаем, нет. И старые, и новые пробеги предлагали возможность участия вне связи с мастерством, практиковали демократичные лимиты времени и подведение итогов по возрастам. Объективное изучение вопроса имеет некоторую сложность. И «новые", и "старые» бегуны неоднородны по опыту, по платежеспособности, по вовлеченности в сектор фитнес-услуг и т.д. Для "новых" бегунов отношение к "старым забегам" базируется не на опыте, а скорее на неких до-

\footnotetext{
${ }^{48}$ Оценка автора, см. также [Adelfinsky, 2021].
} 
мыслах. Стереотипы о беговом движении 2000-х как об “утреннем моционе пенсионеров" ${ }^{49}$, что “любили бегать пенсионеры в трико с вытянутыми коленками" 50 , похоже, порождены бенефициарами трансформации крупнейших беговых серий. На отношение "старых" бегунов к новым пробегам может влиять возникшая экономическая недоступность.

Легко показать, что "адский дизайн" и "ужасная организация", по утверждениям создателей $\mathrm{MM}$ свойственные $\mathrm{MMMM}^{51}$, в действительности можно отнести и на счет новых пробегов. Среди публикаций СМИ есть и те немногие, что противоречат общей картине о новых людях с гораздо лучшей экспертизой. Русская служба BВC откликнулась на "первый качественный" в России пробег статьей "Первый блин Московского марафона", где были отмечены грубые ошибки в длине обеих дистанций (взамен 10 км и 42,195 км - 11,7 км и 43,5 км соответственно), нехватка еды и километровых отметок, путаница на старте, недельная задержка с результатами, отсутствие памятных медалей, застрявших на таможне ${ }^{52}$. Эти ошибки признал сам Д. Тарасов: «Мы молодая команда, не обладающая большим опытом $<\ldots>$. Конечно, у нас многое не получилось" ${ }^{53}$. Претензии в адрес ММ и "Новой Атлетики" активно озвучивались и бегунами, которые жаловались на заметно выросший взнос (о чем упоминалась и в прессе), неудобство регистрации, негибкость сервиса, ощущение снижения качества, требования медсправок: «Питание на троечку, почти одна вода, редко сок и изотоник <...> исчез старый добрый <...> чаек и хлеб" (2012); "ММММ справок не требовал, сейчас развели тягомотину. Неподалеку уже сидят, продают...” (2015); "Надо платить заранее и еще лишний раз приезжать - раньше даже перед стартом номера давали" (2014); "Девочка приехала на один день из Сибири - отправили восвояси" (2013) ${ }^{54}$. Грубые недочеты дебютного ММ (например, длина дистанции) затем были исправлены. Однако журналисты и блогеры продолжали отмечать неприятные моменты ММ: в 2015 г. бегунам на 10 км отказали в питье, лидера забега по ошибке остановили перед самым финишем - мол, "дальше нельзя" 55; в 2016 г.-двухчасовое стояние под дождем при выдаче стартовых пакетов и сорок минут в ожидании старта, ставшая хронической проблема с качеством итоговых результатов ${ }^{56}$ и т. д. Озвученные

\footnotetext{
49 Макушева М. Бегом за преодолением //Ведомости. 2020. 23 сентября. URL: http://vedomosti.ru/opinion/articles/ 2020/09/22/840853-begom-preodoleniem (дата обращения: 10.08.2021).

50 Корнеева Ю. Джоггинг - модное увлечение городских жителей //BFM.ru. 2015. 25 мая. URL: http://bfm.ru/ news/293773 (дата обращения: 10.08.2021).

51 Миронов Ф. Москва - город пьющий или бегающий? // Афиша Daily. 2016. 3 августа. URL: http://daily.afisha.ru/ cities/2499-kuda-pribezhala-moskvy-aktivisty-podvodyat-itogi-sportivnogo-buma/ (дата обращения: 10.08.2021).

52 Нехезин В. Первый блин Московского марафона // Русская служба ВBC. 2013. 27 сентября. URL: http://bbc.com/ russian/russia/2013/09/130927_first_moscow_marathon (дата обращения: 10.08.2021).

53 Там же.

54 Подробности включенного наблюдения изложены в другой статье [Adelfinsky, 2021].

55 Гусейнова М., Парняков В. На Московском марафоне 2015 опять проблемы: полиция, вода, бардак на трассе и, как всегда, результаты //SkiRun.ru. 2015. 20 сентября. URL: http://skirun.ru/2015/09/20/moscow-marathon-2015-itogi/ (дата обращения: 10.08.2021).

56 Гусейнова М. На ММ-2016 установлен рекорд России! Почему этому не стоит радоваться // SkiRun.ru. 2016. 12 октября. URL: http://skirun.ru/articles/20459-moscow-marathon-2016-ustanovlen-rokord-rossii-pochemu-etomunestoit-radovatsa (дата обращения: 10.08.2021); Гусейнова М. Странная статистика результатов на Московском марафоне 2016 //SkiRun. ru. 2016. 3 октября. URL: http://skirun.ru/articles/20378-strannaya-statistika-resultatovna-moscow-marathon-2016 (дата обращения: 10.08.2021).
} 
позиции можно счесть субъективными, впрочем, как и резкую критику ММММ со стороны основателей ММ.

Однако есть пункты, где можно искать объективные критерии оценки. Это дизайн трассы, а также историческая репрезентация главного марафона России. Новая трасса стала медленнее. Среднее время финишера на ММ против ММММ хуже на 15 минут при схожем стандартном отклонении. Полагаем, причина не в мастерстве "новых" бегунов, а в неудачном дизайне новой трассы ММ с холмистым рельефом. Пологая трасса ММММ обеспечивала лучшее личное время, вожделенное большинству участников. Антипатии горожан к новой трассе МM с «перекрытием половины Москвы" выявляет сервис "Яндекс. Пробки", фиксируя поток жалоб в стиле: «Гори в аду, прекрасный Спорткомитет!», «Бегут на расслабоне. Шустрее давайте!", "Достали уже, идиоты...", "Бегают!!! В лесу нельзя, что ли???», "А может, бегунов на стадион?" ${ }^{57}$. Причем до 2013 г. подобного не наблюдалось в связи с крупными забегами. Причина в том, что ММММ и "Марафон Лужники" использовали трассы по набережным центра, обычно в два круга маятником, что слабо влияло на трафик. Инициаторы ММ настояли на кольцевой трассе в один круг с максимальным охватом достопримечательностей, что требует гораздо больших ресурсов от городских властей, а также парализует трафик внутри Садового кольца и окрестных районов. Причем назвать "адским" дизайн конкретно ММММ-2012 (тот, что критиковала А. Боярская) можно расценить как оскорбление чувств верующих. Русская Православная церковь в 2012 г. отмечала 200-летие избавления Москвы от Наполеона. Поскольку частью трассы ММММ овладел крестный ход к чудотворной Смоленской иконе Божией Матери, число кругов марафона увеличили.

Рис. 5. Трассы марафонов МмМм 2011 г. и ММ 2013 r.
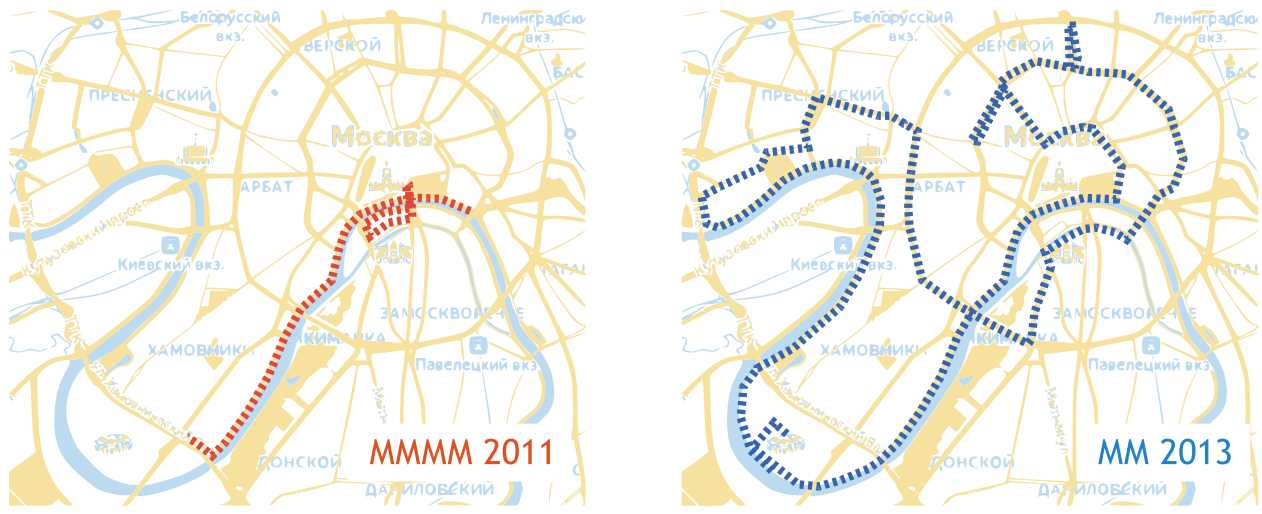

Репрезентация истории бегового движения - еще одна странность ММ. Зарубежные столицы гордятся летописями своих марафонов. В Москве же номинально

\footnotetext{
${ }_{57}$ Макаревич П. Хотел написать пост... что организаторы ММ - молодцы... А потом вспомнил про вот эти скриншоты...//Fb.com. 2014. 21 сентября. URL: http://facebook.com/pavel.makarevich.5/posts/812676668772611 (дата обращения: 10.08.2021).
} 
упразднена история старейших пробегов - объявлены якобы "первые" забеги, "аналогичные западным". Однако речь о наследующих друг друга событиях; а фитнес-бум и на Западе, и в СССР развивался одновременно. Обнуление истории марафонов в России огорчило экспертов и прежних участников, сравнивших это с «взрывом храма Христа Спасителя" и "сносом Ипатьевского дома» ${ }^{58,59 .}$

Очевидная причина непатриотичной исторической репрезентации и неудачного дизайна трассы - отсутствие опыта у инициаторов "первого в России" марафона. В 2000-х годах Д. Тарасов не являлся ни организатором пробегов, ни бегуном. Иногда его представляли как "чемпиона Европы 2007 и бронзового призера Олимпийских игр в Пекине" $60-$ и он действительно был менеджером женской сборной по баскетболу. Полагаем, "люди, знающие толк в марафонах", познакомились с субкультурой бега лишь вследствие найма в проект Nike We Run.

\section{Заключение. Беговой бум как снятие информационной ширмы?}

Итак, почему в 2010-х увлечение бегом обрело популярность, охватив молодое поколение? Полагаем, на беговой бум оказал влияние ряд факторов. Вопервых, драйвером стали кампании по продвижению практики дистанционного бега 2010-2015 гг., развернутые крупными брендами спортивной экипировки в московском регионе. Ведущую роль сыграли забеги Nike Run Moscow и их кампании "Беги в отрыв", "Меньше слов, больше бега", "Ты против себя". Помимо этого, следует упомянуть забеги Adidas и их кампанию “Разбуди район”. Будучи нацелены на молодую аудиторию, кампании Nike и Adidas предлагали регулярные групповые тренировки и участие в пробегах, причем на бесплатной основе.

Во-вторых, сохранившееся до 2000-х годов и продолжавшее развиваться наследие бегового бума 1980-х стало очевидной базой для бегового бума 2010-х, что позволяет говорить о последнем как о второй волне. В московском регионе речь идет о пробегах серий ММММ, "Труд-Лужники", "Космический марафон", "Семь холмов" и др., клубах "Парсек", "Муравей», "Альфа-Битца" и др., а также информационных ресурсах наподобие "Бег и мы", "Бегай с нами", Probeg.org,- таким образом, практика дистанционного бега уже существовала в ее современном виде.

В-третьих, трансформация медиасреды, использование смартфонов и социальных сетей облегчили распространение информации.

В-четвертых, на траекторию бегового бума важное влияние оказала политическая конъюнктура, а именно смена в 2011 г. ряда чиновников Москвы, включая руководителей ведомств культуры, спорта и комплекса «Лужники». Новый баланс власти кардинально изменил доступ к административным ресурсам, значимым для практики массового бега.

Изложенное позволяет обсудить причины скромной популярности бега в 2000-х годах. Опираясь на социологические исследования, К. Чернов, В. Кузнецов и Ю. Каширцев [Чернов, Кузнецов, Каширцев, 1992] отмечали, что до 80 \%

\footnotetext{
58 Ревинский Д. Московский марафон - организация глазами участника // Diesell.livejournal.com. 2013. 22 сентября. URL: http://diesell.livejournal.com/444816.html (дата обращения: 10.08.2021).

59 Арустамов А. Первый год без ММMM //XCsport.ru. 2013. 14 сентября. URL: http://xcsport.ru/blogs/messeges/ messeges_2987.html (дата обращения: 10.08.2021).

${ }^{60}$ Конвенция 3start 2016. 11-13 марта. Официальная брошюра. М. : RTE-group. C. 7.
} 
лиц юношеского возраста и до 55 \% взрослых младше 45 лет испытывают потребность в достижениях при занятиях спортом. Мотив "ради здоровья" не был для них значимым, а ЕВСК ${ }^{61}$ как официальная система мотиваций отрасли ФКиС посильных достижений не предлагала [там же]. В то же время современная практика дистанционного бега и подобных видов спорта в целом зиждется на представлениях о факте финиша как о достижении, чем создается линейка целей и потенциальный мотив для всех. Данные представления разделяются организаторами забегов и большинством их участников, соответствуя так называемой экспрессивной модели спорта [Adelfinsky, 2021]. В свою очередь, П. Виноградов [Виноградов, 1991, 2013], изучая вопросы пропаганды ЗОЖ и массового спорта, указывал на потенциальные возможности СМИ, равно и на то, что они почти не использовались. Порядка 95 \% сообщений прессы на тему ФКиС как в 1990 г., так и в 2009 г. повествовали лишь об итогах соревнований элиты [там же]. Этим поддерживалось рекордистское представление о спорте в целом, а практика массового бега продолжала представляться как некая "физкультура". По сути, необходимо было приоткрыть информационный занавес над практикой бега, создаваемый медиа и официальной системой ФКиС, сосредоточенной на элитном спорте. Отсюда вывод: пропагандировать молодежи ЗОЖ ради здоровья малоэффективно, требуется внедрение экспрессивной модели для массового спорта в целом, - что отчасти и случилось. Полагаем, наша статья вносит также вклад в опровержение "евангельского мифа" о мотивирующей роли элитного спорта [Grix, Carmichael, 2012; De Cocq et al., 2018]. Ввиду очевидной “видимой руки" нет оснований искать "невидимую руку" Олимпиады или Мундиаля.

Логичен вопрос: были ли предприниматели еще одним, пятым фактором? Полагаем, что активность малых бизнесов на "поле" массовых видов стала следствием первичного роста участия в спорте, и лишь затем - новым драйвером фитнес-бума. Речь о двух направлениях. Во-первых, это коммерческие школы обучения бегу, велоспорту, лыжам, триатлону, плаванию и т. д. Во-вторых, это коммерческие забеги и провайдеры ивент-услуг (в том числе и "Новая атлетика"). Беговой бум включал два параллельных процесса. Первый - это рост популярности бега. Кампании брендов вовлекали молодежь, создавая "окно входа" в существовавшую практику. Вклад внесли и возникшие бизнесы "на бегу". Итогом стал 8-кратный рост участия в пробегах за пять лет на фоне прежнего стабильного периода. Второй процесс - это начавшаяся коммерциализация бега. Эффектом активности малых бизнесов стала джентрификация ${ }^{62}$ практики ("бег стал атрибутом современного преуспевающего человека» ${ }^{63}$ ) с 18-кратным ростом стартовых взносов. Возникает вопрос о причинах роста цен, поскольку забеги "нового качества" возникли уже в 2012 г. Вероятно, увлекшиеся "джентри" создавали новый спрос, что и позволило повышать стоимость. Это выводит на проблему коммерциализации

\footnotetext{
$\overline{61}$ Единая всероссийская спортивная квалификация, т. е. система спортивных званий и разрядов.

62 Джентрификацию как понятие в отечественном лексиконе пока ассоциируют с урбанистикой, однако на Западе его используют гораздо шире, в том числе в работах по спорту [Halnon, Cohen, 2006; Cox, 2008, Fawbert, 2010; Fürtjes, 2013]. В частности, в книге П. Купер этому посвящена целая глава: Gentrification of the Marathon [Cooper, 1998].

${ }^{63}$ Андрей Кричмара: “Бег - атрибут преуспевающего человека” //Yarsport.ru. 2016. 19 июня. URL: http://yarsport. ru/other/legkaya-atletika/andrey-krichmara-beg-atribut-preuspevayuschego-cheloveka (дата обращения: 10.08.2021).
} 
так называемой европейской модели спорта ${ }^{64}$. Однако детальное рассмотрение явления требует отдельного исследования.

Тем не менее уже сейчас 18-кратный рост стоимости участия в потенциально наиболее доступном виде спорта позволяет задать вопрос, соответствует ли произошедшее декларируемым целям государственной политики? Можно также спросить, как соотносится с концепцией патриотического воспитания упразднение истории старейших пробегов Москвы и объявление взамен "новых", "аналогичных западным»? Кто помешал продолжить счет Московских марафонов с 1981 г. и тем более "Пробега Труд" - с 1951 г.? Полагаем, эти вопросы можно задать не только руководителям спорта, но множеству представителей управленческой элиты России, также подхваченных фитнес-бумом.

\section{Список литературы (References)}

Аверина М.В. Анализ влияния социокультурных факторов развития общества на формирование спортивных предпочтений поколений Y и Z // Вестник МГлУ. Общественные науки. 2019. Вып. 2. С. 162-175.

Averina M. V. (2019) Analysis of the Influence of Socio-Cultural Factors of the Society Development on the Formation of Sports Preferences of Generations Y and Z. Vestnik of Moscow State Linguistic University. Social Sciences. No.2. P. 162-175. (In Russ.)

Адельфинский А. С. Назло рекордам. Опыт исследования массового спорта. М.: ИД "Дело" РАНХиГС, 2018.

Adelfinsky A. S. (2018) Despite the Records. An Inquiry into Mass Participation Sports. Moscow: Delo RANEPA. (In Russ.)

Адельфинский А. С. Социально-экономическая модель развития массовых видов спорта в России: дисс. ... канд. экон. наук. М. : МГУ, 2014.

Adelfinsky A. S. (2014) Socio-Economic Model of the Mass Participation Sports Development in Russia: PhD Thesis (Economics and National Economy Management). Moscow: Lomonosov Moscow State University. (In Russ.)

Адельфинский А. С. Экономический контекст проблемы “богатых" и "бедных" в массовом спорте и следствия для стратегического управления отраслью //Стратегическое антикризисное управление: глобальные вызовы и роль государства. Сборник VI Международной научно-практической конференции. М.: Перо, 2016. С. 572-578.

Adelfinsky A.S. (2016) The Problem of "Rich" and "Poor" in Mass Participation Sports and Its Implications for the Strategic Governance of Sports Industry. In: Strategic Anti-Crisis Governance: Global Challenges and the Role of the State. Collection of the VI International Scientific and Practical Conference. Moscow: Pero. P. 572-578. (In Russ.)

Виноградов П.А. Анализируя газетные страницы //Теория и практика физической культуры. 1991. № 1. С. 50-52.

\footnotetext{
${ }^{64}$ См. [Andreff, Staudohar, 2000; Nafziger, 2008; Andreff, 2011; Адельфинский, 2014, 2016].
} 
Vinogradov P.A. (1991) Analyzing Newspaper Pages. Theory and Practice of Physical Culture. No. 1. P. 50-52. (In Russ.)

Виноградов П.А., Окуньков Ю. В. О состоянии и тенденциях развития физической культуры и массового спорта в российской федерации (по результатам социологических исследований). М. : Советский спорт, 2013.

Vinogradov P. A., Okunkov Yu. V. (2013) On the State and Trends in the Development of Physical Culture and Mass Sports in the Russian Federation (Based on the Results of Sociological Research). Moscow: Sovetsky Sport. (In Russ.)

Исаев А. А. Спортивная политика России. М.: Советский спорт, 2002. Isaev A. A. (2002) Sports Policy of Russia. Moscow: Soviet Sport. (In Russ.)

Климкович Е. В. Социально-культурный проект как инструмент формирования здорового образа жизни москвича // Вестник Университета Правительства Москвы. 2018. № 2. С. $12-15$.

Klimkovich E. V. (2018) Socio-Cultural Project as a Tool of Shaping a Healthy Lifestyle of a Muscovites. Bulletin of the University of the Government of Moscow. No. 2. P. 12-15. (In Russ.)

Козина И. М., Сережкина Е.В. Концепция кейс-стади в социальных науках и французская традиция монографических исследований трудовых организаций // Социологические исследования. 2015. № 1. С. 64-73.

Kozina I. M., Serezhkina E. V. (2015) Case-Study Concept in Social Sciences and French Traditions of Labor Organization Monographic Studies. Sociological Studies. No. 1. P. 64-73. (In Russ.)

Михель Д. В. Массовый спорт изнутри: опыт включенного наблюдения, представленный ученым-энтузиастом триатлона. Рецензия на книгу: Адельфинский А. С. Назло рекордам. Опыт исследования массового спорта. М.: ИД "Дело" РАНХиГС, 2018 // Социология власти. 2018. Т. 30. № 2. С. 270-281. https://doi.org/10.22394/ 2074-0492-2018-2-270-281.

Mikhel D. V. (2018) Mass Sport from the Inside: A Participant Observation Experience Presented by A Scientist and Triathlete. Review: Adelfinskiy A. S. (2018) In Spite of Records. Mass Sport Investigation Experience, Moscow: Delo RANEPA. Sociology of Power. Vol. 30. No. 2. P. 270-281. https://doi.org/10.22394/2074-0492-2018-2270-281. (In Russ.)

Олефиренко С. С., Буглак Г.Н., Золотарева В.И., Люлько О.М. Медицинское обеспечение марафона // Colloquium-journal. 2019. № 6. C. 26-28. https://doi. org/10.24411/2520-6990-2019-10112.

Olefirenko S. S., Buglak G. N., Zolotareva V.I., Lyulko O. M. (2019) Medical Support of the Marathon. Colloquium-journal. No. 6. P. 26-28. https://doi.org/10.24411/25206990-2019-10112. (In Russ.)

Полухина E. B. Case-study как исследовательская стратегия // Case-study - образовательный и исследовательский опыт в междисциплинарном контексте: сборник научных статей. СПб. : НИУ ВШЭ СПб, 2013. С. 5-12. 
Polukhina E. V. (2013) Case-Study as a Research Strategy. In: Case-Study — Educational and Research Experience in an Interdisciplinary Context. Saint Petersburg: HSE. P. 5-12. (In Russ.)

Пономарев А. В. Разметка изображений массового мероприятия его участниками на основе нематериального стимулирования // Информационно-управляющие системы. 2017. № 3. С. 105-114. https://doi.org/10.15217/issn16848853.2017.3.105.

Ponomarev A. V. (2017) Tagging Public Event Images based on Non-Monetary Incentives. Control in Social and Economic Systems. No. 3. P. 105-114. (In Russ.)

Рябкова Н.И., Кондрашова А. О. Новый аспект работы волонтеров СпбГЭУ в сотрудничестве с "Зенит-Ареной" // Волонтер. 2018. № 4. С. 74-89. URL: https:// unecon.ru/sites/default/files/volonter_2018-no4.pdf (дата обращения: 10.08.2021). Ryabkova N.I., Kondrashova A. O. (2018) New Aspect of Volunteers Working Cooperation With Zenit-Arena. Volunteer. No. 4. P. 74-89. URL: https://unecon.ru/ sites/default/files/volonter_2018-no4.pdf (accessed: 10.08.2021). (In Russ.)

Слугин И.А. Технологии воздействия на массовое поведение посредством социальных медиа // Бизнес. Общество. Власть. 2013. № 17. С. 105-117.

Slugin I. A. (2013) Technologies of Influence on Mass Behavior Through Social Media. Business. Society. Power. No. 17. P. 105-117. (In Russ.)

Чернов К.Л., Кузнецов В. К., Каширцев Ю. А. Проблемы массового спорта //Теория и практика физической культуры. 1992. № 1. С. 34-36.

Chernov K. L., Kuznetsov V. K., Kashirtsev Yu. A. (1992) Problems of Mass Sports. Theory and Practice of Physical Culture. No. 1. P. 34-36. (In Russ.)

Adelfinsky A. (2021) Ordinary, Adequate, and Crazy: Reconsidering the "Pyramid" Metaphor for Mass-participation Sports. The Russian Sociological Review. Vol. 20. No. 2. P. 224-249. https://doi.org/10.17323/1728-192x-2021-2-224-249.

Andreff W. (2011) Some Comparative Economics of the Organization of Sports: Competition and Regulation in North American vs. European Professional Team Sports Leagues. The European Journal of Comparative Economics. Vol. 1. No. 8. P. 3-27.

Andreff W., Staudohar P.D. (2000). The Evolving European Model of Professional Sports Finance. Journal of Sports Economics. Vol. 1. No. 3. P. 257-276. https://doi. org/10.1177/152700250000100304.

Bezold T. (2006) How Is the Marathon Boom Managed? In: D. Papadimitriou (ed.) Book of Abstracts of the 14th EASM European Sport Management Congress. Cyprus: Nicosia. P. 49-51. URL: http://easm.net/download/2006/7ca69c967088c5bc531b8836b98089c4.pdf (accessed: 10.08.2021).

Cooper P. L. (1998) The American Marathon. Syracuse: Syracuse University Press.

Cooper P. L. (1992) The "Visible Hand" on the Footrace: Fred Lebow and the Marketing of the Marathon. Journal of Sport History. Vol. 19. No. 3. P. 244-256. URL: http:// jstor.org/stable/43609652 (accessed: 10.08.2021). 
Cox P. (2013) Class and Competition: The Gentrification of Sport Cycling. In: Dawson T., Thurston K. (eds.) The Bicycle Reader. No. 2. Spring.

De Cocq S., De Bosscher V., Derom I., De Rycke J. (2018) Elite Sport and Sport for All: An Epistemological Paradox. In: Managing Sport in a Changing Europe: Book of Abstracts, European Association for Sport Management. P. 283-284.

Fawbert J. (2011) Social Inclusion and Social Exclusion: 'Gentrification' of Football Fandom. In: Long, J., Fitzgerald H., Millward P. (eds.) Delivering Equality in Sport and Leisure. P. 35-48.

Fürtjes 0. (2013) Gentrifizierung des Stadionpublikums seit den 1990er Jahren? Fußball und der Mythos vom Proletariersport / The Gentrification of Football Since the 1990s? The Myth of Football as a Working-Class Sport. Sport und Gesellschaft. Vol. 10. No. 1. P. 27-54. https://doi.org/10.1515/sug-2013-0103.

Grix J., Carmichael F. (2012) Why do Governments Invest in Elite Sport? A Polemic. International Journal of Sport Policy and Politics. Vol. 4. No. 1. P. 73-90.

Halnon K. B., Cohen S. (2006) Muscles, Motorcycles and Tattoos: Gentrification in a New Frontier. Journal of Consumer Culture. Vol. 6. No. 1. P. 33-56. https://doi.org/ $10.1177 / 1469540506062721$.

Hover P., van der Werff H., Breedveld K. (2015) The Netherlands: Rising Participation Rates, Shifting Segments. In: Scheerder J., Breedveld K., Borgers J. (eds.) Running Across Europe: The Rise and Size of one of the Largest Sport Markets. Houndmills; New York: Palgrave Macmillan. P. 187-207. https://doi.org/10.1057/9781137446374_9.

Nafziger J. A.R. (2008) A Comparison of the European and North American Models of Sports Organisation. The International Sports Law Journal. No. 3-4. P. 100-107.

Nilson F., Lundkvist E., Wagnsson S., Gustafsson H. (2021) Has the Second 'Running Boom' Democratized Running? A Study on the Sociodemographic Characteristics of Finishers at the World's Largest Half Marathon. Sport in Society. Vol. 24. No. 4. P. 659-669. https://doi.org/10.1080/17430437.2019.1703687.

van Bottenburg M., Hover P., Scheerder J. (2010) Don't Miss the Next Boat. Changes and Challenges of the Second Wave of Running for European Athletics' Member Federations. Utrecht: Utrecht School of Governance. URL: http://dspace.library.uu.nl/ handle/1874/305749 (accessed: 10.08.2021).

Scheerder J., Breedveld K., Borgers J. (eds) (2015a) Running Across Europe: The Rise and Size of One of the Largest Sport Markets. Houndmills; New York, NY: Palgrave Macmillan. https://doi.org/10.1057/9781137446374.

Scheerder J., Breedveld K., Borgers J. (2015b) Who Is Doing a Run with the Running Boom? In: Scheerder J., Breedveld K., Borgers J. (eds.) Running Across Europe: The Rise and Size of one of the Largest Sport Markets. Houndmills; New York, NY: Palgrave Macmillan. P. 1-27. https://doi.org/10.1057/9781137446374_1. 